\title{
Are U.S. Coral Reefs on the Slippery Slope to Slime?
}

\author{
J. M. Pandolfi, ${ }^{1 *}$ J. B. C. Jackson, ${ }^{3,4}$ N. Baron, ${ }^{5}$ R. H. Bradbury, ${ }^{6}$ H. M. Guzman, ${ }^{4}$ \\ T. P. Hughes, ${ }^{7}$ C. V. Kappel, ${ }^{8}$ F. Micheli, ${ }^{8}$ J. C. Ogden, ${ }^{9}$ H. P. Possingham, ${ }^{2}$ E. Sala ${ }^{3}$
}

C oral reefs provide ecosystem goods and services worth more than $\$ 375$ billion to the global economy each year (1). Yet, worldwide, reefs are in decline $(1-4)$. Examination of the history of degradation reveals three ways to challenge the current state of affairs $(5,6)$. First, scientists should stop arguing about the relative importance of



The slippery slope of coral reef decline through time.

different causes of coral reef decline: overfishing, pollution, disease, and climate change. Instead, we must simultaneously reduce all threats to have any hope of reversing the decline. Second, the

Enhanced online at www.sciencemag.org/cgi/ content/full/307/5716/1725 scale of coral reef management-with mechanisms such as protected areashas been too small and piecemeal. Reefs must be managed as entire ecosystems. Third, a lack of clear conservation goals has limited our ability to define or measure success.

Large animals, like turtles, sharks, and groupers, were once abundant on all coral reefs, and large, long-lived corals created a complex architecture supporting diverse fish and invertebrates $(5,6)$. Today, the most degraded reefs are little more than rubble, seaweed, and slime. Almost no large animals survive, water quality is poor, and large corals are dead or dying and being replaced by weedy corals, soft corals, and

${ }^{1}$ The Centre for Marine Studies and Department of Earth Sciences, ${ }^{2}$ Department of Mathematics and School of Life Sciences, The University of Queensland, St. Lucia, QLD 4072, Australia. ${ }^{3}$ Center for Marine Biodiversity and Conservation, Scripps Institution of Oceanography, La Jolla, CA 92093, USA. ${ }^{4}$ Smithsonian Tropical Research Institute, Balboa, Republic of Panamá. ${ }^{5}$ National Center for Ecological Analysis and Synthesis, Santa Barbara CA. ${ }^{6}$ Centre for Resource and Environmental Studies, Australian National University, Canberra, ACT 0200, Australia. ${ }^{7}$ Centre for Coral Reef Biodiversity, School of Marine Biology, James Cook University, Townsville, QLD 4811, Australia. ${ }^{8}$ Hopkins Marine Station, Stanford University, CA 93950-3094, USA. ${ }^{9}$ Florida Institute of Oceanography, St. Petersburg, FL 33701, USA.

*Author for correspondence. E-mail: j.pandolfi@ uq.edu.au seaweed $(2,7,8)$. Overfishing of megafauna releases population control of smaller fishes and invertebrates, creating booms and busts. This in turn can increase algal overgrowth, or overgrazing, and stress the coral architects, likely making them more vulnerable to other forms of stress. This linked sequence of events is remarkably consistent worldwide (see top figure, this page).

Even on Australia's Great Barrier Reef (GBR), the largest and best-managed reef in the world, decline is ongoing (9). Australia's strategy, beginning with the vision to establish the world's largest marine park in 1976, is based on coordinated management at large spatial scales. Recently more than one-third of the GBR was zoned "no take," and new laws and policies to reduce pollution and fishing are in place (10). Evaluating benefits of increased notake zones will require detailed follow-up, but smaller-scale studies elsewhere support increased protection. Two neighboring countries, the Bahamas (11) and Cuba (12), have also committed to conserve more than $20 \%$ of their coral reef ecosystems. By contrast, the Florida Keys and main Hawaiian Islands are far further down the trajec- tory of decline (see bottom figure, this page), yet much less action has been taken.

What is the United States doing to enhance its coral reef assets? In the Florida Keys National Marine Sanctuary, the Governor and the National Oceanic and Atmospheric Administration (NOAA) agreed in 1997 to incorporate zoning with protection from fishing and water quality controls (13). But only $6 \%$ of the Sanctuary is zoned no take, and these zones are not strategically located. Conversion of 16,000 cesspools to centralized sewage treatment and control of other land-based pollution have only just begun. Florida's reefs are well over halfway toward ecological extinction and much more impaired than reefs of Belize and all but one of the Pacific reefs in the figure below (6). Large predatory fishes continue to decrease (14), reefs are increasingly dominated by seaweed $(15,16)$, and alarming diseases have emerged (17).

Annual revenues from reef tourism are $\$ 1.6$ billion (1), but the economic future of the Keys is gloomy owing to accelerating ecological degradation. Why? Without a clear goal for recovery, development and ratification of the management plan became a goal in itself.

Reefs of the northwest Hawaiian Islands have been partially protected by isolation from the main Hawaiian Islands (which show

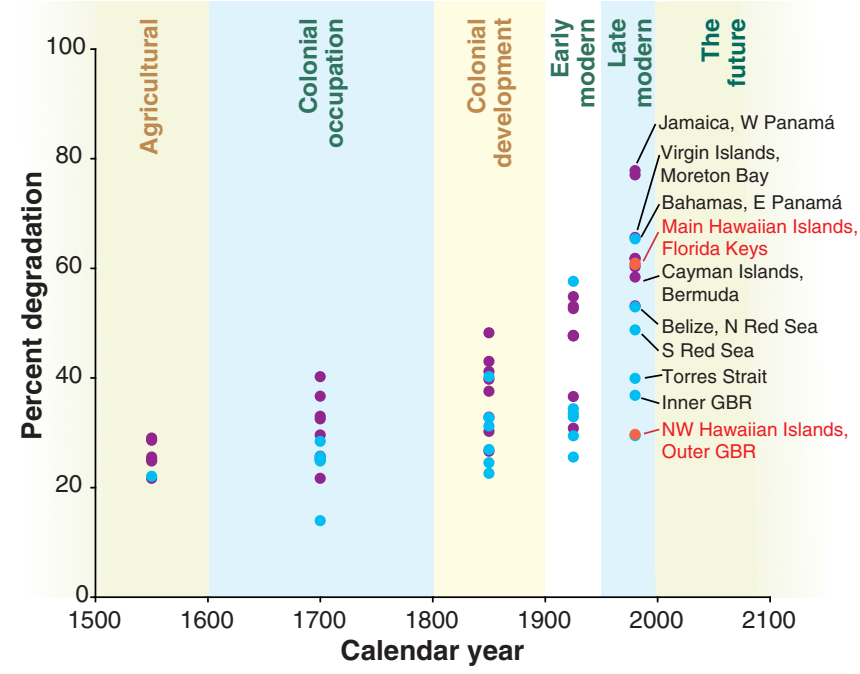

Past and present ecosystem conditions of 17 coral reefs, based on historical ecology (6). The method consists of determining the status of guilds of organisms for each reef with published data, performing a multivariate, indirect gradient analysis on the guild status database, and estimating the location of each reef along a gradient of degradation from pristine to ecologically extinct reefs. Green, Caribbean sites; blue, Australian and Red Sea sites; red, U.S. reefs from the most recent cultural period. 
A ROADMAP FOR REVERSING THE TRAJECTORY OF DECLINE OF U.S. CORAL REEFS

Threat (time frame)
Overfishing
(years)

Overfishing

(decades)

\section{Pollution}

(years-decades)

Coastal development (years-decades)

Global change

(decades)

\section{Critical first step}

Immediate increase of cumulative

no-take areas of all U.S. reefs to $>30 \%$; reduce fishing efforts in adjacent areas

Establishment of large fish, shark, turtle, and manatee breeding programs; mandatory turtle exclusion devices (TEDs) and bycatch reduction devices (BRDs)

Stringent controls over land-based pollution

Moratorium on coastal development in proximity to coral reefs

International engagement in emission caps
Results

Increase in short-lived species, such as lobsters, conch, parrotfish, and sea urchins

Increase in megafauna populations

Increase in water quality

Increase in coral reef habitat

Reduction in global sea surface temperatures and $\mathrm{CO}_{2}$

\section{Benefits}

Economic viability to lost or weakened fisheries; reduction in algal competition with corals

Return of key functional components and trophic structure

Reduction in algal competition with corals; reduced coral disease Increase of coral reef populations (i.e., reduced mortality)

Lower incidence of coral bleaching; increase calcification potential degradation similar to that of the Florida Keys) and are in relatively good condition (see figure at the bottom of page 1725). Corals are healthy $(2,18)$, and the average biomass of commercially important large predators such as sharks, jacks, and groupers is 65 times as great (19) as that at Oahu, Hawaii, Maui, and Kauai. Even in the northwestern islands, however, there are signs of decline. Monk seals and green turtles are endangered $(20,21)$; large amounts of marine debris are accumulating, which injure or kill corals, seabirds, mammals, turtles, and fishes $(2,18,22)$; and levels of contaminants, including lead and PCBs are high (18).

Until recently, small-scale impacts from overfishing and pollution could be managed locally, but thermal stress and coral bleaching are already changing community structure of reefs. Impacts of climate change may depend critically on the extent to which a reef is already degraded $(8,23)$. Polluted and overfished reefs like in Jamaica and Florida have failed to recover from bouts of bleaching, and their corals have been replaced by seaweed (2). We believe that restoring food webs and controlling eutrophication provides a first line of defense against climate change $(8,23)$; however, slowing or reversing global warming trends is essential for the long-term health of all tropical coral reefs.

For too long, single actions such as making a plan, reducing fishing or pollution, or conserving a part of the system were viewed as goals. But only combined actions addressing all these threats will achieve the ultimate goal of reversing the trajectory of decline (see the table above).

We need to act now to curtail processes adversely affecting reefs. Stopping overfishing will require integrated systems of notake areas and quotas to restore key functional groups. Terrestrial runoff of nutrients, sediments, and toxins must be greatly reduced by wiser land use and coastal development. Reduction of emissions of greenhouse gases are needed to reduce coral bleaching and disease. Progress on all fronts can be measured by comparison with the past ecosystem state through the methods of historical ecology to determine whether or not we are succeeding in ameliorating or reversing decline. Sequential return of key groups, such as parrot fish and sea urchins that graze down seaweed; mature stands of corals that create forest-like complexity; and sharks, turtles, large jacks, and groupers that maintain a more stable food web $(4,5,6,24)$ constitutes success.

This consistent way of measuring recovery (see the figure at the bottom of page 1725 ) and the possibility of short-term gains set a benchmark for managing other marine ecosystems. Like any other successful business, managing coral reefs requires investment in infrastructure. Hence, we also need more strategic interventions to restore species that provide key ecological functions. For example, green turtles and sea cows not only once helped maintain healthy seagrass ecosystems, but also were an important source of high-quality protein for coastal communities (25).

Our vision of how to reverse the decline of U.S. reefs rests on addressing all threats simultaneously (see the table above). By active investment, major changes can be achieved through practical solutions with short- and long-term benefits. Short-lived species, like lobster, conch, and aquarium fish will recover and generate income in just a few years, and benefits will continue to compound over time. Longer-lived species will recover, water quality will improve, and the ecosystem will be more resilient to unforeseen future threats. Ultimately, we will have increased tourism, and the possibility of renewed sustainable extraction of abundant megafauna. One day, reefs of the United States could be the pride of the nation.

\section{References}

1. D. Bryant et al., Reefs at Risk. A Map-Based Indicator of Threats to the World's Coral Reefs (World Resources Institute, Washington, DC, 1998).

2. C. R. Wilkinson, Status of Coral Reefs of the World:
2004 (Global Coral Reef Monitoring Network and Australian Institute of Marine Science, Townsville, Australia, in press); vol. 1 is available at www.gcrmn.org/status2004.asp.

3. T. A. Gardener et al., Science 301, 958 (2003).

4. D. R. Bellwood, T. P. Hughes, C. Folke, M. Nyström, Nature 429, 827 (2004)

5. J. B. C. Jackson et al., Science 293, 629 (2001).

6. J. M. Pandolfi et al., Science 301, 955 (2003).

7. T. P. Hughes et al., Science 265, 1547 (1994)

8. N. Knowlton, Proc. Natl. Acad. Sci. U.S.A. 98, 5419 (2001).

9. Great Barrier Reef Marine Park Authority, Overview: The current status of the Great Barrier Reef www.gbrmpa.gov.au/corp_site/info_services/publications/sotr/overview/index.html

10. Great Barrier Reef Marine Park Authority, New Policy Web site: www.gbrmpa.gov.au/corp_site/management/zoning/zoning_publications.html

11. D. R. Brumbaugh et al., Proceedings of the Forum 2003 Conference, Nassau, Bahamas, 30 June to 4 July 2003 (College of the Bahamas, Nassau, Bahamas, 2003).

12. R. Estrada et al., El sistema nacional de areas marinas protegidas de Cuba [Center for Protected Areas (CNAP), Havana, Cuba, 2003].

13. Florida Keys National Marine Sanctuary, Draft Management Plan/Environmental Impact Statement (Department of Commerce, National Oceanic and Atmospheric Administration, Washington, DC, 1995), vol. 1, pp.1-323.

14. J.A. Bohnsack, Gulf Caribbean Res. 14, 1 (2003)

15. W. C. Jaap et al., Environmental Protection Agency/ National Oceanographic and Atmospheric Administration (NOAA) Coral Reef Evaluation and Monitoring Project: 2002 Executive Summary (Report of the Florida Fish and Wildlife Conservation Commission, Tallahassee, and the University of Georgia, Athens, 2003).

16. J.W. Porter et al., in The Everglades, Florida Bay, and Coral Reefs of the Florida Keys: An Ecosystem Handbook, J.W. Porter and K. G. Porter, Eds. (CRC Press, Boca Raton, FL, 2002), pp. 749-769.

17. C. D. Harvell et al., Science 296, 2158 (2002).

18. J. Maragos, D. Gulko, Eds., Coral Reef Ecosystems of the Northwestern Hawaiian Islands: Interim Results Emphasizing the 2000 Surveys (U.S. Fish and Wildlife Service and Hawaii Department of Land and Natural Resources, Honolulu, HI, 2002).

19. A. M. Friedlander, E. E. DeMartini, Mar. Ecol. Prog. Ser. 230, 253 (2002).

20. International Union for the Conservation of Nature and Natural Resources, Red List of Threatened Species; available at www.redlist.org

21. NOAA, www.nmfs.noaa.gov/prot_res/species/.

22. C. Safina, Eye of the Albatross (Holt, New York, 2003).

23. T. P. Hughes et al., Science 301, 929 (2003).

24. T. Elmqvist et al., Front. Ecol. Environ. 1, 488 (2003).

25. J. B. C. Jackson, Coral Reefs 16, S23 (1997).

10.1126/science. 1104258

Supporting Online Material

www.sciencemag.org/cgi/content/full/307/5716/1725/DC1 
Post date 17 June 2005

Policy Forum: "Are U.S. coral reefs on the slippery slope to slime?" by J. M. Pandolfi et al. (18 Mar. 2005, p. 1725). In the bottom figure on p. 1725, Caribbean sites are purple (not green as described in the legend), and some data points are not seen because of superimposed dots. Otherwise, the labels point to the dots in order. For example, the Bahamas and eastern Panamá are represented by the purple dot partly showing above the red dot for the Main Hawaiian islands and Florida Keys. The lettering for the Outer Great Barrier Reef (Outer GBR) should be black. 